\title{
STUDI PERUBAHAN LAHAN PANTAI KOLONGAN DI KELURAHAN MALALAYANG DUA KOTA MANADO
}

\section{(Study on Kolongan Coast Changes in Malalayang Dua Manado City)}

\author{
Richard R. Mumu ${ }^{1 *}$, Rignolda Djamaluddin ${ }^{1}$, Adrie A. Tarumingkeng ${ }^{1}$ \\ ${ }^{1}$ Program Studi IImu Kelautan, Fakultas Perikanan dan IImu Kelautan, \\ Universitas Sam Ratulangi, Manado. \\ *e-mail : ichadmm@mail.com
}

Kolongan Coast has been used intensively, and one of that is the construction of T-groins to protect the coast. Effectiveness of the construction to reduce actions of hydro-oceanography factors and to tray sediments were studied. It is well known that hydro-oceanography factors play significant role as an agent geomorphic, and these factors contribute in large to development process of coastal area. This research was designed to observe the coast area condition and analyzed the change through sattelite images in google, and analyzed of the observed coastal area current. Result of research indicated that the T-groins protect the coastal farm rear. To support this observation, coastal elevation was measured, and the result indicated that the coast is flat and sloping. Besides result of sediment granulometry analysis showed that the coast area is in the process off sedimentation. The current varried among observation points ranging from 0,080,47 knot uring spring tide and 0,27 - 0,55 knot during low tide.

Keywords: Kolongan Coast, T-groins, agents geomorphic, sediment

Teridentifikasi Pantai Kolongan telah dimanfaatkan secara intensif, salah satunya yaitu dengan dibangunnya bangunan pelindung pantai T-groins. Efektivitas peran bangunan pelindung pantai T-groins dalam meredam aksi faktor hidrooseanografi serta menjalankan fungsinya dalam menangkap sedimen, merupakan faktor yang dikaji dalam studi ini. Diketahui bahwa faktor hidro-oseanografi sebagai agen geomorfik, merupakan kontributor terbesar dalam proses perkembangan suatu lahan pantai. Penelitian ini dilakukan dengan cara mengamati kondisi lahan pantai dan menganalisis perubahan lahan pantai melalui pengamatan citra google serta menganalisis karakteristik arus yang terjadi pada lahan yang diobservasi. Hasil penelitian menunjukkan $T$-groins melindungi lahan pantai dibelakangnya. Hal ini ditunjang dengan hasil pengukuran kemiringan lereng yang menunjukkan keberadaan lereng pantai yang cenderung datar dan landai. Berdasarkan hasil analisis granulometri sedimen, Pantai Kolongan sementara atau sedang dalam proses pendeposisian sedimen. Data hasil pengukuran arus di Pantai Kolongan bervariasi di setiap titik pengamatan, dengan kisaran kecepatan arus 0,08 knot 0,47 knot saat pasang dan 0,27 knot $-0,55$ knot saat surut.

Kata kunci : Pantai Kolongan, T-groins, agen geomorfik, sedimen 


\section{PENDAHULUAN}

Pantai adalah daerah di tepi perairan yang dipengaruhi oleh air pasang tertinggi dan air surut terendah (Triatmodjo, 1999). Selanjutnya Dahuri $d k k$, (2004) menguraikan daerah pantai atau wilayah pantai secara luas disebut juga wilayah pesisir, dapat diartikan sebagai suatu daerah peralihan antara daratan dan lautan. Sebagai suatu daerah peralihan antara daratan dan lautan, pantai menampilkan corak yang unik melalui proses dan perkembangannya.

Dikemukakan oleh Sunarto (1991), proses geomorfik yang menentukan pembentukan dan perkembangan lahan pantai, secara langsung mempengaruhi garis pantai. Maju atau mundurnya garis pantai terhadap laut merupakan fenomena lingkungan yang mengindikasikan adanya proses perkembangan lahan pantai. Dengan bantuan data tentang garis pantai dapat dilihat mengenai perubahan lahan pantai dari satu waktu geologi ke waktu yang lain.

Pethick (1997) mengemukakan, proses geomorfik pada daerah pantai berlangsung secara aktual yang diperankan oleh unsur-unsur dari faktor hidro-oseanografi. Proses yang tersusun atas rangkaian proses-proses konstruksional dan destruksional ini menghasilkan bentuklahan yang selanjutnya dapat mengalami perubahan corak atau perkembangan bentuk. Hasil dari proses ini berkontribusi pada dinamika garis pantai dalam mempertahankan fungsi alamiahnya sebagai pembatas daratan dan lautan. Selain proses geomorfik, aktifitas manusia di wilayah pantai juga berperan dalam pembentukan serta perubahan lahan pantai. Pembabatan hutan mangrove, tambang pasir, pelabuhan, dan reklamasi dapat menyebabkan perubahan di wilayah pantai. Pantai Kolongan yang terdapat di Kelurahan Malalayang , teridentifikasi adanya bangunan pelindung pantai groins ( $T$ groins). Menurut Anonimous (2010), T- groins ini dibangun dengan tujuan untuk mengembalikan garis pantai akibat kerusakan yang diakibatkan karena adanya abrasi. Selanjutnya dijelaskan bahwa pembangunan seri $T$-groins ini tidak cukup efisien karena di beberapa bagian antara seri T-groins, garis pantai terlihat mundur.

\section{METODE PENELITIAN}

Kegiatan penelitian ini dilaksanakan dalam lingkup kerja Laboratorium Morfologi Pantai dan HidroOseanografi. Penerapan metode tersebut ditempuh dalam survei lahan pantai dan serangkaian kegiatan yang dilaksanakan di ruang laboratorium untuk pengolahan dan penyajian data hasil. Metode ini diterapkan dalam pemetaan lahan pantai dengan pengamatan citra google untuk mengidentifikasi perubahan lahan pantai. Selanjutnya diikuti dengan survei lapangan dalam rangka pengukuran morfometri lahan, penarikan contoh sedimen serta pengukuran arah dan kecepatan arus.

Lokasi survei berada di Pantai Kolongan yang merupakan daerah tempat penempatan bangunan pelindung pantai T-groins (gambar 1).

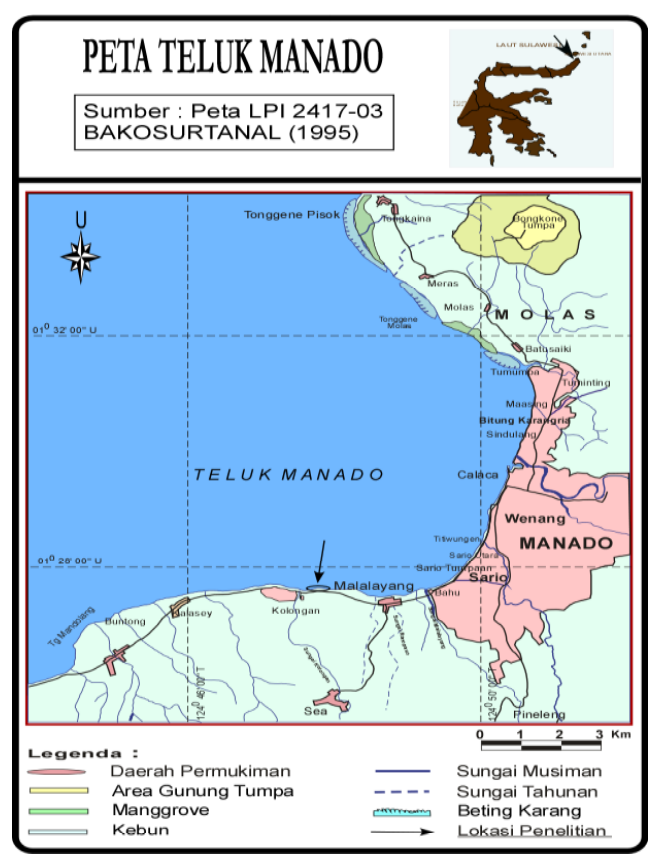

Gambar 1. Lokasi Penelitian 
Kawasan ini terletak pada posisi geografis sekitar $1^{\circ} 27^{\prime} 37.28 " \mathrm{U}$ $1^{\circ} 27^{\prime} 35.83^{\prime \prime U ~ / ~ 1244 ' ~} 37.27^{\prime \prime T}$ $124^{\circ} 48^{\prime} 8.18^{\prime \prime} \mathrm{T}$ dan merupakan bagian yang berada di Teluk Manado yang menghadap ke arah Utara.

Untuk mendeskripsikan kondisi lahan pantai, kegiatan yang dilakukan yaitu berupa observasi dan pemetaan lahan pantai. Observasi yang telah dilakukan yaitu berupa pemotretan lokasi survei, pengukuran morfometri lahan pantai dan penarikan contoh sedimen. Sedangkan pemetaan lahan pantai dilakukan dengan menggunakan GPS.

Morfometri lahan diukur melalui penentuan kemiringan lereng gisik. Pengukuran kemiringan lereng ini dibagi atas 7 profil, dengan menggunakan peralatan profiler, yaitu dua tonggak papan yang dihubungkan dengan tali sepanjang $100 \mathrm{~cm}$ dan diberi busur derajat pada salah satu tonggak tersebut. Sudut yang terbentuk. menggambarkan perbedaan ketinggian pada permukaan lahan yang diamati.

Penarikan contoh sedimen dimaksudkan untuk melihat distribusi granulometri sedimen di lahan pantai yang diobservasi. Kegiatan ini meliputi 2 tahapan yaitu penarikan contoh sedimen, selanjutnya penanganan dan pengolahan data di laboratorium Morfologi dan HidroOseanografi Pantai.

Pengukuran morfometri dan pemetaan lahan pantai juga dijadikan faktor dalam penentuan perubahan lahan pantai. Sketsa yang dihasilkan dari hasil observasi dan pemetaan merupakan suatu dasar acuan untuk menggambarkan kondisi pantai dan kedudukan garis pantai sekarang ini.

Pengukuran arah dan kecepatan arus dilakukan dengan bantuan alat Floater Current Meter (FCM) dan kompas , caranya yaitu dilakukan dari atas perahu yang berada dalam keadaan diam. Penentuan titik-titik pengamatan arus dilakukan dengan menggunakan Global Positioning System (GPS), dan titik pengamatan arus berjumlah 7 titik.

Analisis data kemiringan lereng gisik diolah menurut kaidah goniometri berdasarkan data hasil pengukuran sudut

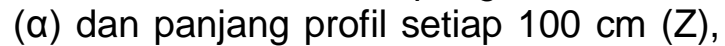
untuk memperoleh satuan jarak $\left(X_{i}\right)$ dan satuan tinggi $\left(Y_{i}\right)$, dimana $X_{i}=Z \cos \alpha$ dan $Y_{i}=Z$ sin a (Sosrodarsono dan Takasaki, 1997). Hasil pengolahan data ini selanjutnya diarahkan untuk menunjukkan hubungan regresi antara tinggi permukaan lahan $(Y)$ dan jaraknya dari garis pantai $(X)$ berdasarkan jumlah kumulatifnya dengan menggunakan persamaan linier $(\mathrm{Y}=\mathrm{a}+\mathrm{bx})$. Kemudian ditentukan nilai presentasi kemiringan menurut hasil perhitungan dari rumus koefisien regresi berikut ini.

$$
|b|=\frac{\Sigma X Y-(\Sigma X)(\Sigma Y) / n}{\Sigma X^{2}-(\Sigma X)^{2} / n}
$$

Untuk contoh sedimen diawali dengan penarikan contoh sedimen dilanjutkan dengan penanganan dan pengolahan data. Contoh sedimen yang dicuplik sebanyak 100-150 gr dicuci kemudian dikeringkan. Setelah kering ditimbang berat bersih kemudian diayak menggunakan ayakan yang ada di laboratorium MORPHO. Kelompok butiran sedimen yang tertinggal pada setiap bagian ayakan dituangkan ke dalam wadah untuk dilakukan penimbangan. Hasil penimbangan ini dicatat berat kumulatif menurut ukuran diameter ayakan dimana dengan bantuan komputer hasilnya digambarkan sebagai dasar dalam analisis granulometrinya. Terhadap grafik yang terbentuk, observasi dilakukan untuk menemukan besaran-besaran distribusi granulometri sedimen, yaitu : $\varphi$ (phi-kecil $)_{5}, \varphi_{16}, \varphi_{25}, \varphi_{50}$, $\varphi_{75}, \varphi_{84}$, dan $\varphi_{95}$. Besaran-besaran tersebut dinyatakan dalam bentuk nilai menurut skala Wenworth-Udden berdasarkan transfer nilai menurut skala AFNOR ( $\alpha$ ). Sesuai peralatan pengayak yang digunakan, kisaran nilai yang terukur dan adalah -13 a (alpha) sampai $13 \alpha$ atau $-4,33 \varphi$ (phi) sampai 4,33 $\varphi$.

Selanjutnya untuk menentukan peubah distribusi granulometri sedimen berdasarkan hasil observasi besaran- 
besaran tersebut, dikerjakan secara manual atau lewat bantuan pengolah data Excel dengan mengikuti Folk dan Ward (Dyer, 1986), dengan formula sebagai berikut :

a. Rataan Empirik ( $\left.\mathbf{M}_{\mathbf{Z}}\right)$

$\mathbf{M}_{\mathbf{z}}=\left(\varphi_{16}+\varphi_{50}+\varphi_{84}\right) / 3$

b. Penyortiran ( $\sigma_{1}$, sigma satu)

$\sigma_{1}=\left(\varphi_{84}-\varphi_{16}\right) / 4+\left(\varphi_{95}-\varphi_{5}\right) / 6,6$

c. Kemencengan Kurva $\left(\mathrm{S}_{\mathbf{k}}\right)$

$S_{\mathbf{k}}=\left[\left(\varphi_{16}+\varphi_{84}-2 \varphi_{50}\right) / 2\left(\varphi_{84}-\varphi_{16}\right)\right]$ $+\left[\left(\varphi_{5}+\varphi_{95}-2 \varphi_{50}\right) / 2\left(\varphi_{95}-\varphi_{5}\right)\right]$

\section{d. Peruncingan Kurva (Kg)}

$\mathbf{K g}=\left(\varphi_{95}-\varphi_{5}\right) / 2,44\left(\varphi_{75}-\varphi_{25}\right)$

Data hasil observasi dan pemetaan lahan pantai disajikan dalam bentuk peta atau sketsa bentuklahan. Dari peta atau sketsa bentuklahan yang telah disajikan, dengan bantuan hasil pengamatan citra google serta program aplikasi yang ada dapat diestimasikan perubahan lahan pantai pada kawasan yang disurvei.

Untuk perhitungan kecepatan arus digunakan rumus petunjuk kecepatan (Thamrin dan Jamal, 2003), sebagai berikut :

$$
\mathrm{V}=\mathbf{s} / \mathbf{t}
$$

\section{HASIL DAN PEMBAHASAN}

Berdasarkan hasil survei dan pengamatan di lapangan, Pantai Kolongan merupakan tempat berbagai macam aktivitas manusia seperti tempat penambatan perahu bagi nelayan, tempat berdagang, juga oleh sebagian masyarakat dijadikan tempat rekreasi keluarga.

Data hasil marking GPS dianalisis menggunakan program Surfer 6.0 yang kemudian dilanjutkan dengan menggunakan program Canvas 9.0 menghasilkan sketsa lahan pantai.

Morfometri lahan ditampilkan dalam bentuk kemiringan lereng dan panjang lereng. Pengukuran kemiringan lereng ini dibagi atas 7. Berdasarkan hasil pengukuran di lapangan, kemiringan lereng dari profil $1-7$ terkriteria dari 13,28 \% (lereng miring), 2,86\% (lereng datar), 0,95\% (lereng datar), 1,47 \% (lereng datar), 1,76\% (lereng datar), 3,58 \% (lereng landai), dan $7,26 \%$ (lereng landai).

Panjang lereng yang terukur pada lahan Pantai Kolongan masuk pada dua klasifikasi yaitu lereng pendek dan lereng agak panjang. Berdasarkan hasil observasi panjang lereng untuk profil 1 , profil 2, profil 4, profil 6, dan profil 7 terklasifikasi pada lereng pendek dengan panjang lereng masing-masing sebesar 19 m, 50 m, 48 m, 33 m, dan 18 m. Untuk profil 3 dan profil 5 terklasifikasi pada lereng agak panjang dengan panjang lereng sebesar $53 \mathrm{~m}$ dan $67 \mathrm{~m}$.

Komposisi sedimen yang ditelaah terbanyak adalah pasir sedang tapi secara keseluruhan sedimen pada lahan Pantai Kolongan disusun oleh ukuran butiran yang beragam (gambar 2). Jenis sedimen pada lahan pantai Kolongan terdiri dari batu, kerikil, pasir kasar, pasir sedang, pasir halus, pasir sangat halus dan debu. sedimen pasir sedang presentasinya paling banyak $(28,12 \%)$ kemudian diikuti oleh pasir halus $(25,85$ $\%)$, kerikil (15,24 \%), pasir kasar $(13,89$ $\%)$, pasir halus $(10,47 \%)$, batu $(5,11 \%)$ dan debu merupakan presentasi paling sedikit $(1,32 \%)$.

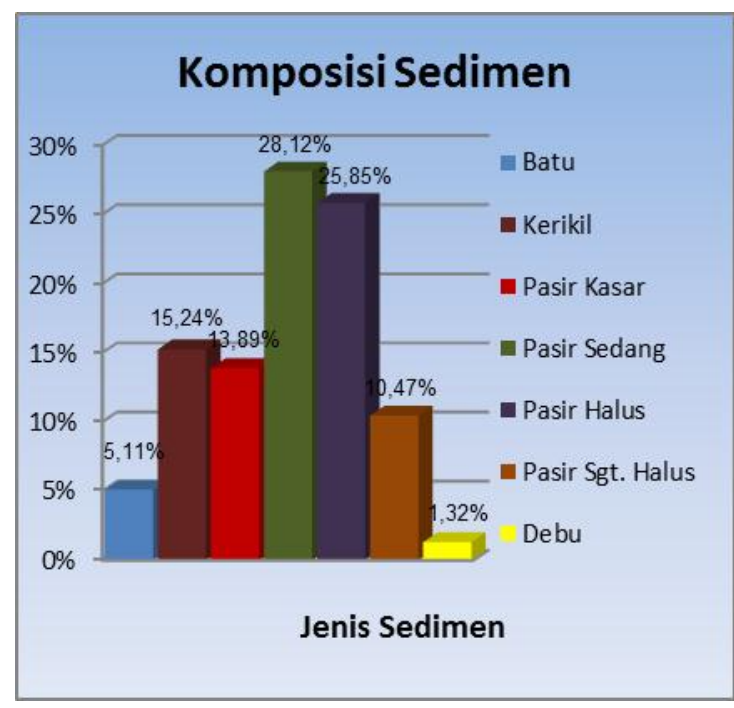

Gambar 2. Komposisi Sedimen 
Tabel 1. Hasil Analisis Granulometri Sedimen

\begin{tabular}{|c|c|c|}
\hline $\begin{array}{c}\text { Peubah Granulometri } \\
\text { Sedimen }\end{array}$ & Kisaran Nilai & Kelas/ Kriteria Terbesar \\
\hline Rataan Empirik $(\mathrm{Mz})$ & $0,37-2,49$ & Pasir sangat kasar \\
\hline Penyortiran $\left(\sigma_{1}\right)$ & $0,77-3,12$ & Tersortir sangat buruk \\
\hline Kemencengan Kurva $(\mathrm{Sk})$ & $-0,53-0,22$ & Asimetris ke ukuran besar \\
\hline Peruncingan Kurva $(\mathrm{Kg})$ & $0,62-1,68$ & Mesokurtik \\
\hline
\end{tabular}

Rataan empirik (Mz) secara umum dipahami sebagai ukuran pemusatan dari distribusi granulometri sedimen. Kisaran rataan empirik pada sedimen tercuplik yaitu antara 0,37 - 2,49 $\mathrm{mm}$ dengan variasi klasifikasi pada pasir kasar, pasir sedang, dan pasir sangat kasar. Berdasarkan hasil pengamatan pada keseluruhan profil, ukuran pemusatan ke pasir sangat kasar (tabel 1)

dalam sedimentologi renurut Davis (1983), penyortah keseragaman ukuran butiran sedimen sampel sebagai refleksi kondisi selama pendeposisian. Berdasarkan nilai penyortiran distribusi granulometri sedimen lahan pantai yang diobservasi, sedimennya terklasifikasi tersortir sedang sampai dengan tersortir sangat buruk. Namun demikian kriteria tersortir sangat buruk pada golongan pasir sangat kasar merupakan yang terbanyak dalam proses penyortiran ini.

Kemencengan kurva adalah ketidaksimetrisan atau kesimetrisan suatu sebaran frekuensi ukuran butiran sedimen. Peubah distribusi granulometri sedimen kemencengan kurva pada lahan yang diobservasi memiliki nilai yang bervariasi menurut ruang pencuplikan contoh sedimen. Hasil interpretasi granulometri untuk nilai kemencengan pada sedimen tercuplik, dominan tergolong pada kriteria asimetris ke ukuran besar (sangat negatif) yang tersebar pada profil 2, 4, 5, dan 7.

Peruncingan kurva sebagai peubah distribusi granulometri, pada dasarnya adalah ukuran peruncingan dari kurva sebaran frekuensi ukuran sedimen.
Berdasarkan penampilan kurva, hasil interpretasi grafik menunjukkan kurva berbentuk mesokurtik yang terbanyak dibandingkan bentuk kurva yang lain. Bentuk-bentuk kurva tersebut pada dasarnya merupakan refleksi dari aksi laut yang bekerja pada lahan Pantai Kolongan.

Secara umum lahan Pantai Kolongan yang diobservasi mengalami perkembangan lahan yang cukup signifikan. Kehadiran tumbuhan mangrove di lahan observasi, indikasi terjadi perubahan substrat dalam hal ini terjadinya deposisi sedimen berukuran kecil (pasir ukuran halus) dan terangkatnya permukaan dasar. Hal lain juga yang terlihat yaitu terjadinya kenaikan muka air laut yang ditandai dengan hilangnya tumpukan batu pada ujung Timur dari seri T-groins, tetapi garis pantai di belakangnya terlihat maju ke arah laut.

Fungsi bangunan pelindung pantai seri $T$-groins dalam meredam aksi fisik hidro-oseanografi merupakan faktor yang berpengaruh dalam perubahan suatu lahan pantai. Keberadaan bangunan pelindung pantai ini dipandang mampu melindungi garis pantai yang ada dibelakangnya. Berdasarkan hasil observasi pada lahan Pantai Kolongan terlihat dengan adanya bangunan pelindung pantai T-groins, mampu melindungi ekosistem pantai yang ada dibelakangnya. Ini ditunjukkan dengan kemiringan lereng pantai yang cenderung datar dan landai pada hampir sepanjang lahan pantai yang diobservasi. 

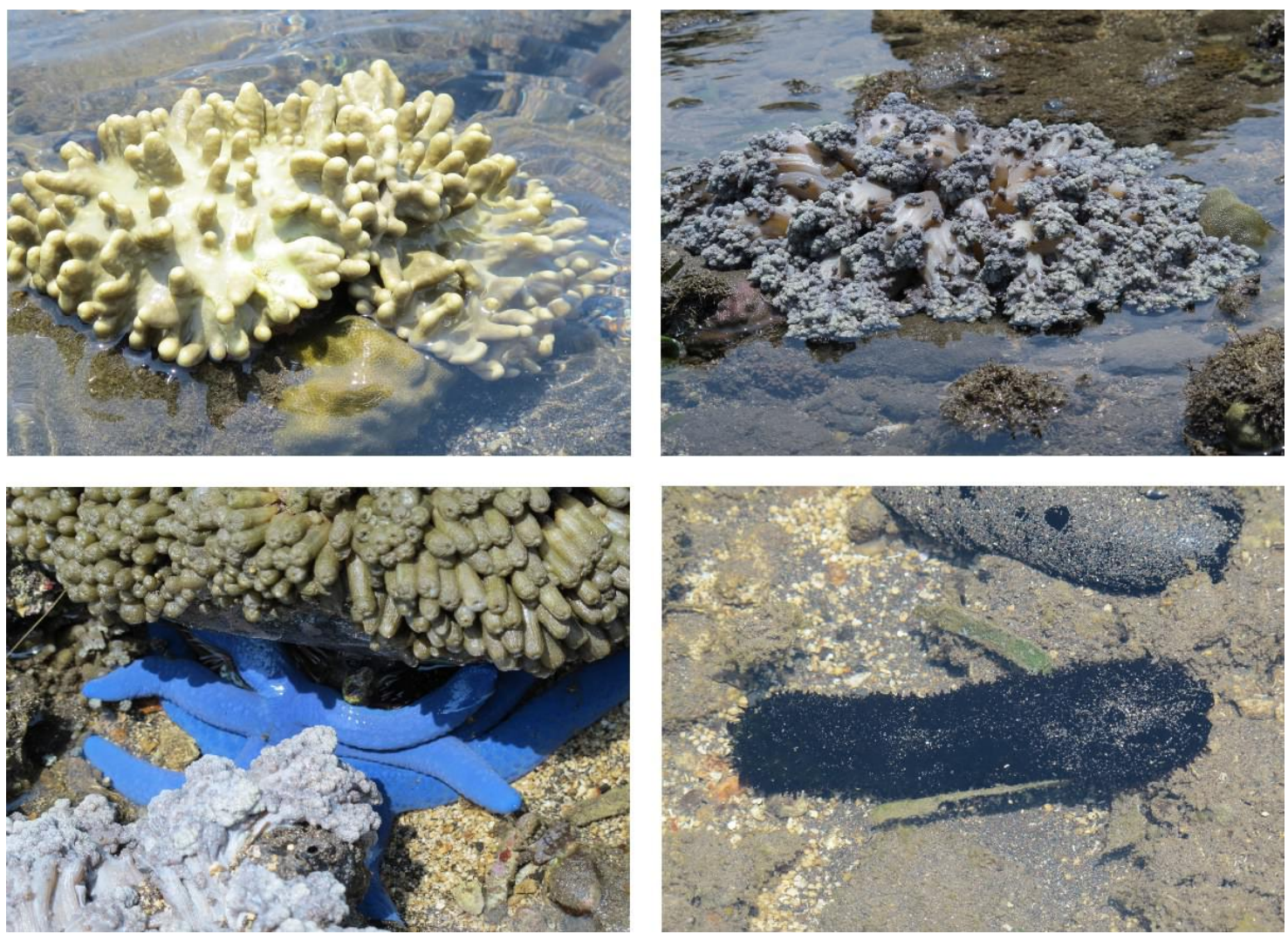

\section{Gambar 4. Spesies Karang Yang Berasosiasi Dengan Hewan Laut.}

Indikasi lain yang menunjukkan efektifitas bangunan pelindung pantai yang ada di lahan Pantai Kolongan yaitu pada beberapa bagian sel dari seri $T$ groins ini terlihat adanya beberapa spesies karang. Beberapa spesies karang ini berasosiasi dengan hewan karang lainnya seperti bintang laut, teripang dan ikan (gambar 4).

Pengukuran arus yang dilakukan di Pantai Kolongan diperoleh data kecepatan arus yang bervariasi di setiap titik pengamatan. Kisaran kecepatan arus sekitar 0,08 knot - 0,47 knot pada saat pasang dan 0,27 knot - 0,55 knot pada saat surut. Kecepatan arus terkecil terukur pada titik pengamatan 7 pada saat pasang dan kecepatan arus terbesar teramati pada titik pengamatan 5 pada saat surut. Rata-rata kecepatan arus pada saat pasang adalah 0,21 knot dan pada saat surut sekitar 0,37 knot.

Arus musim secara global yang sempat dipetakan oleh Wyrtki (1961) tampak memberi pengaruh pada pergerakan arus di daerah teluk. Arus yang bergerak dari arah Barat sepanjang sepanjang pantai Utara semenanjung Minahasa telah mengakibatkan arah arus di sekitar Tanjung Mandolang bergerak masuk ke arah Timur (ke dalam teluk). Pada bagian Utara mulut teluk sampai tengah dalam teluk, arus sering bergerak ke arah Tenggara. Sedangkan pada bagian Selatan teluk, baik saat pasang maupun surut arah arus sering berlawanan. Hal ini kemungkinan terjadi konvergen dua arah arus yang disebabkan pergerakan arus oleh angin musim dari arah Barat yang berlawanan dengan pergerakan arus oleh pasut dari arah Timur Teluk Manado (Siwy 2012).

Pengamatan pola pergerakan arus, mengindikasikan arus yang bergerak dari arah Baratdaya pada saat pasang mampu mendeposisikan sedimen yang cenderung ke pasir sangat kasar di sepanjang seri T-groins. Hal ini dapat dilihat pada hasil analisis granulometri sedimen, dimana pada profil 2 dan 7 contoh sedimen tercuplik dominan pada pasir sangat kasar. Selanjutnya 
pengamatan pola pergerakan arus saat surut yang bergerak ke arah Timurlaut, mampu mendeposisikan sedimen pada ujung sebelah Barat seri T-groins. Dan dari hasil analisis granulometri sedimen pada titik pengamatan ini, menunjukkan sedimen yang dideposisikan cenderung ke pasir kasar.

Uraian di atas menunjukkan besarnya peran faktor hidro-oseanografi dalam hal ini arus dalam mendeposisikan sedimen pada suatu lahan pantai. Dimana pendeposisian sedimen pada suatu lahan pantai mengindikasikan dapat terjadinya perubahan kenampakan lahan pantai berupa perubahan kemiringan lereng lahan pantai maupun komposisi sedimen yang menghamparinya.

\section{KESIMPULAN}

Pengamatan kemiringan lereng dan analisis granulometri sedimen, Pantai Kolongan mengalami pendeposisian sedimen yang mengindikasikan bahwa lahan pantai ini berpeluang terbentuk lahan pantai baru. Melalui pengamatan hasil marking citra google pada ujung Barat dan ujung Timur dari seri $T$-groins terlihat terjadi penumpukan sedimen. Pada bagian tengah dari seri $T$-groins ini garis pantainya mundur jika dihubungkan dengan kemiringan lereng dan hasil analisis granulometri sedimen, pada bagian ini sementara atau sedang terjadi pendeposisian sedimen. Arah arus yang dominan mengalir dari arah Baratdaya pada saat pasang dan mengalir dari arah Timurlaut saat surut mengindikasikan adanya pendeposisian sedimen pada ujung Barat dan Timur dari seri T-groins.

\section{DAFTAR PUSTAKA}

Anonimous, 2010. DRAFT TECHNICAL NOTES (Working Group 4). Kondisi Eksisting, Permasalahan dan Solusi Perlindungan Pantai Manado
Berdasarkan Hasil Kajian Sel dan Pemodelan Perubahan Garis Pantai. Manado.

BAKOSURTANAL, $1995 . \quad$ Peta Lingkungan Pantai Indonesia. Skala 1: 50.000. Lembar LPI 2417-03 Manado. 1 lembaran.

Dahuri, R., J. Rais, S.P. Ginting, dan M.J. Sitepu, 2004. Pengelolaan Sumberdaya Wilayah Pesisir dan Lautan Secara Terpadu. P.T Pradnya Paramita. Jakarta. 328 hal.

Davis, R.A., 1983. Depositional Systems : A Genetic Approach to Sedimentary Geology. Prentice - Hal, Inc, USA. $669 \mathrm{p}$.

Dyer, R.,1986. Coastal and Estuarine Sediment Dynamics. John Wiley and Sons, Chiechester. 342 hal.

Pethick. J., 1997. An Introduction to Coastal Geomorphology. Edward Arnold London. 260 hal.

Siwy, A., 2012. Pergerakan Massa Air Permukaan di Teluk Manado Saat Musim Utara. Skripsi dalam Bidang Geomorfologi Pantai. FPIK UNSRAT. 70 hal.

Sosrodarsono, S., dan M. Takasaki, 1997. Pengukuran Topografi dan Teknik Pemetaan. PT Pradnya Paramita. Jakarta. 313 hal.

Sunarto, 1991. Geomorfologi Pantai. Pusat Antar Universitas, Ilmu Teknik. Universitas Gadjah Mada. Yogyakarta. 50 hal.

Thamrin dan A. Jamal, 2003. Rahasia Penerapan Rumus-Rumus Fisika SMU. Gitamedia Press. 192 hal.

Triatmodjo, B., 1999. Teknik Pantai. Beta Offset. Yogyakarta. 397 hal.

Wyrtki, K., 1961. Physical Oceanography of The Southeast Asian Waters. La Jolla. California. 